\title{
Expression of mutant TDP-43 induces neuronal dysfunction in transgenic mice
}

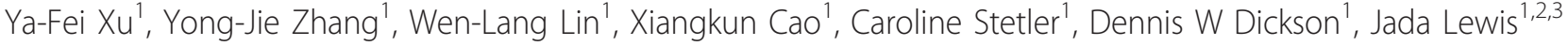 \\ and Leonard Petrucelli ${ }^{*}$
}

\begin{abstract}
Background: Abnormal distribution, modification and aggregation of transactivation response DNA-binding protein 43 (TDP-43) are the hallmarks of multiple neurodegenerative diseases, especially frontotemporal lobar degeneration with ubiquitin-positive inclusions (FTLD-U) and amyotrophic lateral sclerosis (ALS). Researchers have identified 44 mutations in the TARDBP gene that encode TDP-43 as causative for cases of sporadic and familial ALS http://www.molgen.ua.ac.be/FTDMutations/. Certain mutant forms of TDP-43, such as M337V, are associated with increased low molecular weight (LMW) fragments compared to wild-type (WT) TDP-43 and cause neuronal apoptosis and developmental delay in chick embryos. Such findings support a direct link between altered TDP-43 function and neurodegeneration.

Results: To explore the pathogenic properties of the M337V mutation, we generated and characterized two mouse lines expressing human TDP-43 (hTDP-43 ${ }_{\text {M337V }}$ ) carrying this mutation. $h T D P-43_{\text {M337V }}$ was expressed primarily in the nuclei of neurons in the brain and spinal cord, and intranuclear and cytoplasmic phosphorylated TDP-43 aggregates were frequently detected. The levels of TDP-43 LMW products of $\sim 25 \mathrm{kDa}$ and $\sim 35 \mathrm{kDa}$ species were also increased in the transgenic mice. Moreover, overexpression of hTDP-43 ${ }_{\mathrm{M} 337 \mathrm{~V}}$ dramatically down regulated the levels of mouse TDP43 (mTDP-43) protein and RNA, indicating TDP-43 levels are tightly controlled in mammalian systems. TDP-43 ${ }_{\text {Mз37v }}$ mice displayed reactive gliosis, widespread ubiquitination, chromatolysis, gait abnormalities, and early lethality. Abnormal cytoplasmic mitochondrial aggregates and abnormal phosphorylated tau were also detected in the mice.
\end{abstract}

Conclusion: Our novel TDP-43 $3_{\text {M3з7V }}$ mouse model indicates that overexpression of hTDP-43 ${ }_{\text {M337V }}$ alone is toxic in vivo. Because overexpression of hTDP-43 in wild-type TDP-43 and TDP-43 $3337 \mathrm{~V}$ mouse models produces similar phenotypes, the mechanisms causing pathogenesis in the mutant model remain unknown. However, our results suggest that overexpression of the hTDP- $43_{\mathrm{M} 337 \mathrm{~V}}$ can cause neuronal dysfunction due to its effect on a number of cell organelles and proteins, such as mitochondria and TDP-43, that are critical for neuronal activity. The mutant model will serve as a valuable tool in the development of future studies designed to uncover pathways associated with TDP-43 neurotoxicity and the precise roles TDP-43 RNA targets play in neurodegeneration.

Keywords: aggregation, ALS, mitochondria, mouse model, tau

\section{Background}

TDP-43 is the major component of ubiquitinated inclusions in most cases of ALS and FTLD-U [1,2], and the link between TDP-43 mutations and neurodegeneration was first established in 2008 [3,4]. Autosomal dominant mutations in TARDBP, the gene encoding TDP-43, are

\footnotetext{
* Correspondence: petrucelli.leonard@mayo.edu

'Department of Neuroscience, Mayo Clinic, (4500 San Pablo Road), Jacksonville, (32224), USA

Full list of author information is available at the end of the article
}

associated with sporadic and familial ALS [3-7]. TDP-43 is a ubiquitously expressed 414-amino acid nuclear protein and a highly conserved heterogeneous nuclear ribonucleoprotein (hnRNP). TDP-43 has high-binding affinity for the (TG) motif and is involved in gene transcription, pre-mRNA splicing, mRNA stability, and mRNA transport $[8,9]$. Under disease conditions, TDP43 is truncated, phosphorylated, ubiquitinated and aggregated both in the nucleus and cytoplasm. Under such conditions, cytoplasmic TDP-43 aggregation
Ciomed Central

() 2011 Xu et al; licensee BioMed Central Ltd. This is an Open Access article distributed under the terms of the Creative Commons Attribution License (http://creativecommons.org/licenses/by/2.0), which permits unrestricted use, distribution, and reproduction in any medium, provided the original work is properly cited. 
coincides with the depletion of nuclear TDP-43. The manner through which TDP-43 causes neurodegeneration has not been identified; however, recently TDP-43 mouse models generated by our group and others demonstrate that overexpression of TDP-43 [either wild-type, A315T mutant, G348C or $\triangle$ NLS (defective nuclear localization signal TDP-43)] is toxic and can cause neurodegeneration in the central nervous system [10-16]. That being said, the various TDP-43 transgenic models exhibit other similarities as well as differences. For instance, most transgenic models showed increased ubiquitin levels, TDP-43 fragmentation, phosphorylation, gliosis, motor functional impairments, and shortened lifespan. On the other hand, neuronal loss, caspase activation, redistribution of TDP-43 from nuclei to cytoplasm, cytoplasmic TDP-43 inclusions, down regulation of endogenous mTDP-43 and abnormal mitochondrial aggregation were either only seen in some of those TDP-43 transgenic mice, or not examined. To further confirm the toxic effect of TDP-43 overexpression and to specifically study mutant TDP-43, we generated transgenic mice expressing hTDP-43 $3_{\mathrm{M} 337 \mathrm{~V}}$ under control of the mouse prion $(\mathrm{PrP})$ promoter [17].

In the TDP- $43_{\mathrm{M} 337 \mathrm{~V}}$ mice, hTDP- $43_{\mathrm{M} 337 \mathrm{~V}}$ is mainly expressed in the brain and spinal cord, a finding that is consistent with transgenic mice overexpressing wildtype TDP-43 that we previously reported [11]. TDP$43_{\mathrm{M} 337 \mathrm{~V}}$ mice exhibited certain features similar to those seen in ALS, such as TDP-43 cleavage, phosphorylation, aggregation, increased ubiquitination, gliosis, gait disturbances, and early lethality; however, the mice also exhibited other features not yet reported in humans, which may be due to the effect of hTDP $-43_{\mathrm{M} 337 \mathrm{~V}}$ overexpression. Such features include: down regulation of mTDP43, abnormal mitochondrial aggregation and abnormal tau phosphorylation.

\section{Results}

\section{Generation of transgenic mice overexpressing hTDP-43 M337v protein}

To explore the pathogenic properties of mutant (M337V) TDP-43, we generated transgenic mice using the mouse prion promoter to constitutively drive expression of full-length hTDP-43 carrying the M337V mutation. Three (Lines 1, 4, and 6) of eight independent founder lines showed germline transmission. The expression level of human TDP-43 was low in line 1 ( $\sim 20 \%$ of endogenous levels), while lines 4 and line 6 had similar hTDP-43 expression levels to that of wildtype TDP-43 mice (TDP- $43_{\mathrm{WT}}$ line $3 \mathrm{c}$ hereafter termed TDP- $43_{\mathrm{WT}}$ ), which we previously generated with the same promoter [11] (Figure 1A, B). Biochemical analyses of hTDP-43 $3_{\mathrm{M} 337 \mathrm{~V}}$ showed that protein expression was highest in the brain and spinal cord, with low levels in other tissues (Figure 1C). The immunohistochemistry (IHC) of hemizygous mice showed that hTDP-43 M337V expression was primarily in nuclei and distributed throughout the gray matter of the spinal cord and brain (Figure 1D, E). Hemizygous mice from all lines were phenotypically, histologically, and immunohistochemically indistinguishable from NT mice up to 12 months of age, currently the oldest age available. Given the similar levels of expression between lines 4 and 6 , the full characterization of line 4 is shown and all subsequent description of TDP $-43_{\mathrm{M} 337 \mathrm{~V}}$ mice refer to homozygous mice from line 4 unless otherwise noted. The expression level of hTDP- $43_{\mathrm{M} 337 \mathrm{~V}}$ in the brains of homozygous mice was about $1.9 \pm 0.06$ fold over that of hemizygous mice (Figure 2A, B). The total levels of TDP-43 protein (human and mouse TDP-43) in the brains of hemizygous and homozygous mice were $1.6 \pm 0.03$ and $2.7 \pm$ 0.08 fold that of endogenous mouse TDP-43 in the nontransgenic mice (NT), respectively (Figure 2A, C). These results obtained from hTDP-43 $3_{\mathrm{M} 337 \mathrm{~V}}$ compared with total TDP-43 indicated that endogenous mTDP-43 protein levels were likely down regulated in TDP- $43_{\mathrm{M} 337 \mathrm{~V}}$ mice, in a dose-dependent fashion. We confirmed that mTDP-43 was similarly down regulated at the mRNA level ( $\sim 20 \%$ and $30 \%$ reduction of mTDP- 43 , respectively, compared to NT mice) using real time-PCR analyses of hemizygous and homozygous brains (Figure 2D). The mRNA levels of hTDP-43 in the brain of homozygous mice were $1.86 \pm 0.14$ fold of that in the hemizygous mice (Figure 2E), consistent with the hTDP-43 protein levels. Moreover, the $\sim 25 \mathrm{kDa}$ and $\sim 35 \mathrm{kDa}$ TDP-43 LMW species also increased significantly in the hemizygous and homozygous mice, and their levels correlated with the levels of full-length TDP43 (Figure 2F, G).

At approximately post-natal day 21, homozygous TDP- $43_{\mathrm{M} 337 \mathrm{~V}}$ mice began to have body tremors and difficulty recruiting their hindlimbs (not shown). They failed to show proper escape extension by splaying their hindlimbs upon elevation, as shown by their NT counterparts (Figure 3A, B). They displayed an irregular, dragging gait pattern, due at least in part to limb weakness (Figure 3C, D). By $~ 1$ month old, homozygous TDP $-43_{\mathrm{M} 337 \mathrm{~V}}$ mice had significantly lower brain and body weight compared with their NT and hemizygous littermates (Figure 3E, F). Due in part to muscle weakness, homozygous TDP $-43_{\mathrm{M} 337 \mathrm{~V}}$ mice were unable to feed from a food hopper, lost the ability to right themselves, became moribund and required euthanasia. Approximately $70 \%$ of the homozygous TDP $-43_{\mathrm{M} 337 \mathrm{~V}}$ mice became moribund by 1 month of age, which was statistically significant compared with NT and hemizygous littermates (Figure 3G). We had previous success (unpublished) extending the lifespan of mouse models 


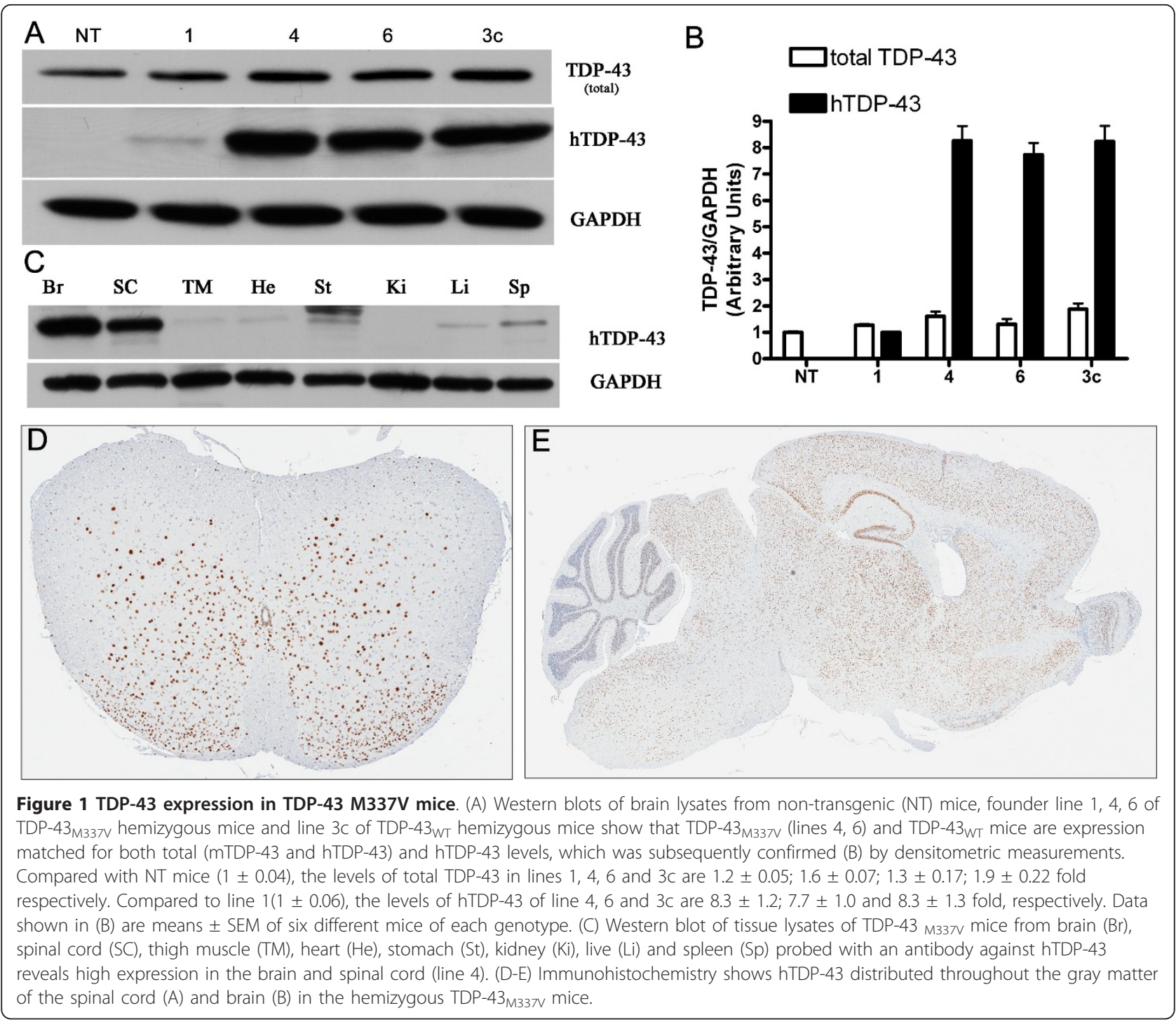

that showed early lethality through the use of intensive care such as delayed weaning and supplementing diets with gel and dough. We have now employed similar measures in an effort to prolong the lives of homozygous TDP $-43_{\mathrm{M} 337 \mathrm{~V}}$ transgenic mice. The phenotype of the homozygous TDP $-43_{\mathrm{M} 337 \mathrm{~V}}$ mice from line 6 (not shown) was similar to that described for line 4 .

\section{Pathological alteration of TDP-43}

Immunohistochemistry was performed on both line 4 and line 6 of TDP $-43_{\mathrm{M} 337 \mathrm{~V}}$ and NT mice. The results showed that TDP-43 was mostly in nuclei in the brain and spinal cord of TDP $-43_{\mathrm{M} 337 \mathrm{~V}}$ and NT mice and that the TDP $-43_{\mathrm{M} 337 \mathrm{~V}}$ mice specifically expressed high levels of hTDP-43 that were not seen in the controls (Figure 4A-C). Cytoplasmic TDP-43 was detected with either a human TDP-43 specific antibody or total TDP-43 antibody that recognized both human and mouse TDP43. Cytoplasmic TDP-43 was detected in spinal cord neurons and less frequently in the brainstem and cortex of TDP-43 $3_{\mathrm{M} 337 \mathrm{~V}}$ mice (Figure $4 \mathrm{~A}, \mathrm{~B}, \mathrm{D}$ and $4 \mathrm{E}$ arrowhead, Table 1). Abnormally phosphorylated (pS403/ pS404) TDP-43 (pTDP-43) was frequently located within nuclear bodies or diffusely within the cytoplasm of motor neurons in the anterior horns of the spinal cord of TDP-43 $3_{\mathrm{M} 337 \mathrm{~V}}$ mice (Figure $4 \mathrm{G}, \mathrm{H}$ arrowheads, cytoplasmic pTDP-43 was detected in the posterior horn of TDP $-43_{\mathrm{M} 337 \mathrm{~V}}$ mice and in the brainstem $(<5$ neurons/section; Table 1). pTDP-43-immunoreactive nuclear bodies were not detected in the brains of TDP$43_{\mathrm{M} 337 \mathrm{~V}}$ mice (Table 1 ). Multiple small, distinct, cytoplasmic inclusions that were immunoreactive for pTDP43 were frequently observed within neurons in layer $\mathrm{V}$ arrows) but not in the NT mice (Figure 4I). Far less 


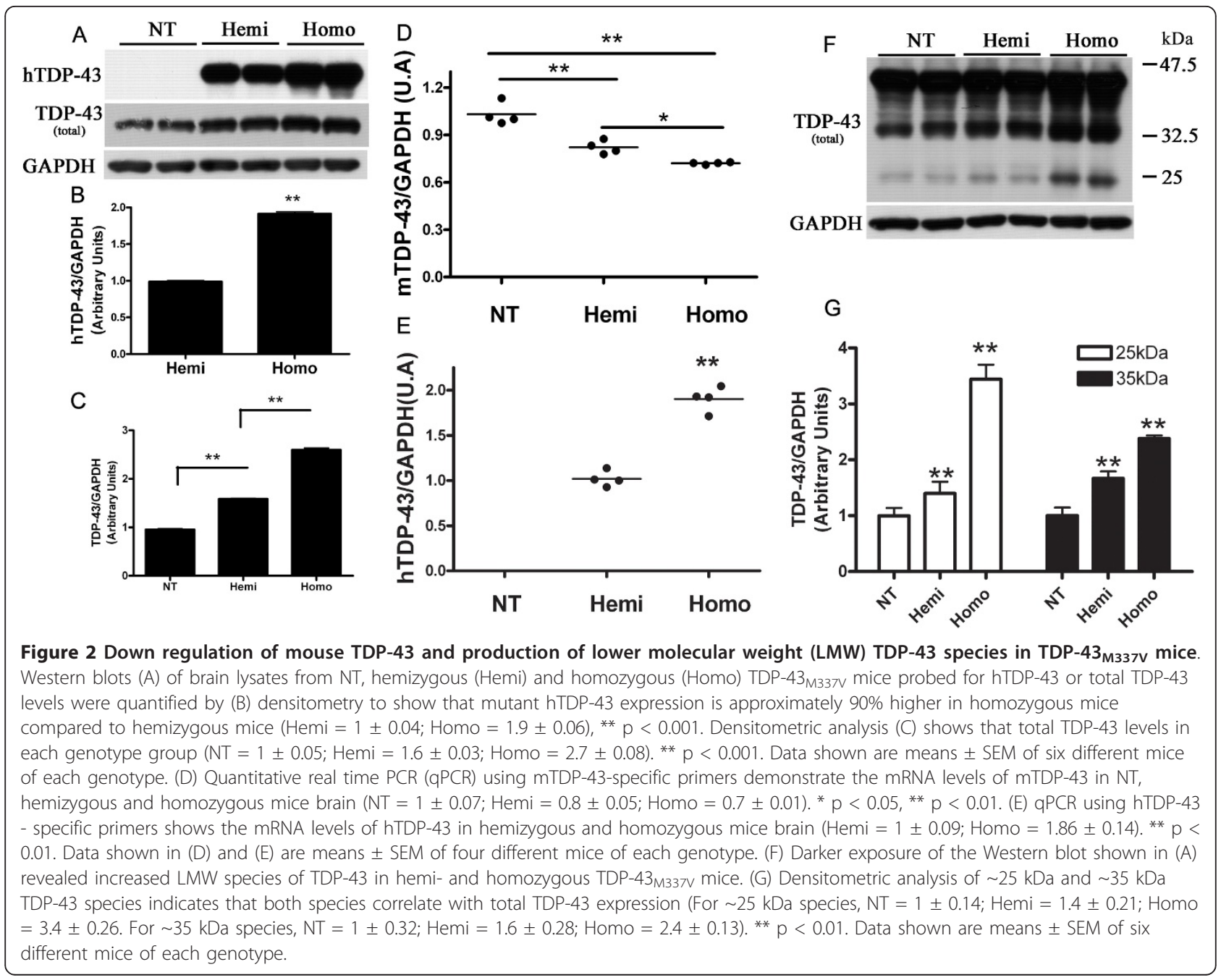

of the cortex of TDP $-43_{\mathrm{M} 337 \mathrm{~V}}$ mice (Figure 4J, K, arrows) that were not observed in NT controls (Figure $4 \mathrm{~L})$. The extent and distribution of these features in the TDP-43 $3337 \mathrm{~V}$ mice was similar to that observed in our previously reported TDP-43 $3_{\mathrm{WT}}$ mice [11].

\section{Cytoplasmic eosinophilic aggregates, ubiquitination, and gliosis in TDP-43 ${ }_{\text {M337v }}$ mice}

A striking histological feature in TDP $-43_{\mathrm{M} 337 \mathrm{~V}}$ mice was the presence of cytoplasmic eosinophilic aggregates (Figure $5 \mathrm{~A}$ ) located within the neurons of the anterior horn of the spinal cord and less frequently in the posterior horn and brainstem. These aggregates were absent from NT mice (Figure 5B). Neuronal loss due to apoptosis was not detected in TDP $-43_{\mathrm{M} 337 \mathrm{~V}}$ mice, as assessed by TUNEL staining and staining for activated caspase 3 (data not shown); however, increased ubiquitination and reactive gliosis were observed in TDP-43 $3337 \mathrm{~V}$ mice and not in NT mice (Figure 5C-J). Ubiquitination was both widespread, and generally increased, in both the nucleus and cytoplasm of neurons in spinal cord and brain (Figure $5 \mathrm{C}, \mathrm{E}$ ). Ubiquitination was more widespread than cytoplasmic TDP-43 or phospho-TDP-43 aggregates (Table 1), and co-immunoprecipitation studies indicated that hTDP-43 was not ubiquitinated (Additional file 1). Reactive gliosis was also seen in the TDP $-43_{\mathrm{M} 337 \mathrm{~V}}$ mice, as GFAP-positive astrocytes and IBA-1-positive microglia were elevated in the spinal cord and brainstem of TDP $-43_{\mathrm{M} 337 \mathrm{~V}}$ mice compared with NT mice (Figure 5GJ; Table 1). Each of these features observed in the TDP$43_{\mathrm{M} 337 \mathrm{~V}}$ mice was similar to that observed in our previously reported TDP-43 $3_{\mathrm{WT}}$ model [11]. Homozygous TDP $-43_{\text {M } 337 \mathrm{~V}}$ mice from line 4 and 6 (not shown) showed similar pathological changes.

Abnormal mitochondrial aggregates in TDP-43 ${ }_{\mathrm{M} 337 \mathrm{~V}}$ mice The eosinophilic aggregates in spinal motor neurons of TDP- $43_{\mathrm{M} 337 \mathrm{~V}}$ mice were immunoreactive for the mitochondrial marker, COX-IV (Figure 6A), which indicates the aggregates were composed of abnormal clusters of 

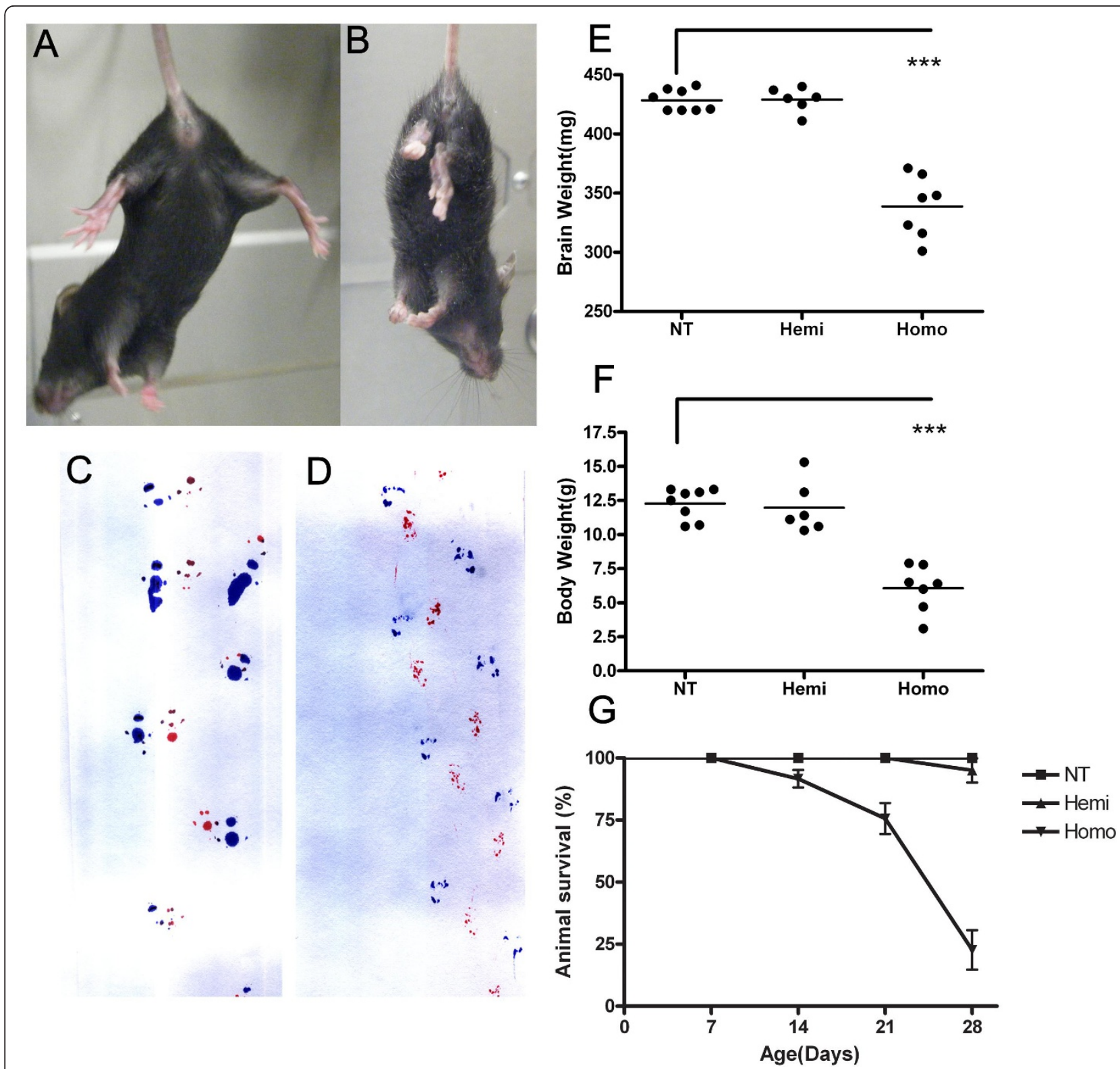

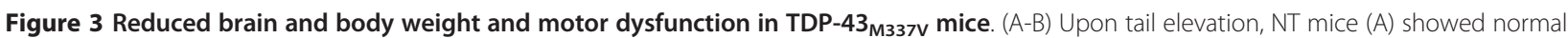
escape response by splaying their hind limbs while homozygous TDP-43 ${ }_{\mathrm{M} 337 \mathrm{~V}}$ mice (B) held their hind limbs close to their body and failed to show proper escape extension. (C-D) Gait of NT and TDP-43 $3_{\text {M337v }}$ mice was evaluated by inked foot placement on paper. 1 month old (C) NT mice show normal foot placement and gait; whereas, (D) homozygous TDP-43 ${ }_{M 337 v}$ mice showed an irregular, inwardly-placed foot falls with a dragging pattern. Forepaws and hind paws were coated in red and blue ink, respectively, to evaluate placement of paws during travel. (E) At 1 month, brain weight and (F) body weight of homozygous TDP-43 $3_{M 337 v}$ mice was significantly lower than that of age-matched NT and hemizygous mice. Brain weight: NT $=428 \pm 9$ mg; Hemi $=429 \pm 11 \mathrm{mg} ; \mathrm{Homo}=338 \pm 29 \mathrm{mg}$. Body weight: $\mathrm{NT}=12.3 \pm 1 \mathrm{~g} ; \mathrm{Hemi}=12 \pm 2 \mathrm{~g} ; \mathrm{Homo}=6 \pm 2 \mathrm{~g}$. Data shown are the means \pm SEM of 6-8 mice per group. ${ }^{* *} \mathrm{p}<0.0001$. (G) Hemizygous TDP- $43_{\text {M337V }}$ mice were mated, and the survival of the resulting pups of each genotype was determined. The results are plotted as a percentage of pups alive per postnatal day of life. Survival rate for all cohorts were calculated using Kaplan-Meier methods ( $p<0.001$ for overall log-rank test). Homozygous TDP-43M337v mice had higher mortality (about $70 \%$ death) around 1 month of age, which was statistically significant compared with NT and hemizygous littermates $(p<0.001)$.

mitochondria. NT mice (Figure 6B) did not show altered redistribution of COX-IV immunostaining into the juxtanuclear pattern observed in the TDP-43 $3_{\mathrm{M} 337 \mathrm{~V}}$ mice. Electron microscopic (EM) results confirmed that the majority of neuronal cytoplasmic inclusions in the spinal motor neurons of TDP- $43_{\mathrm{M} 337 \mathrm{~V}}$ mice contained aggregates of mitochondria (Figure $6 \mathrm{C}$ ) that were occasionally surrounded by a core of microtubules $(20 \mathrm{~nm})$ in random orientations (Figure 6D). The aggregated mitochondria showed variable degrees of loss of inner cristae 


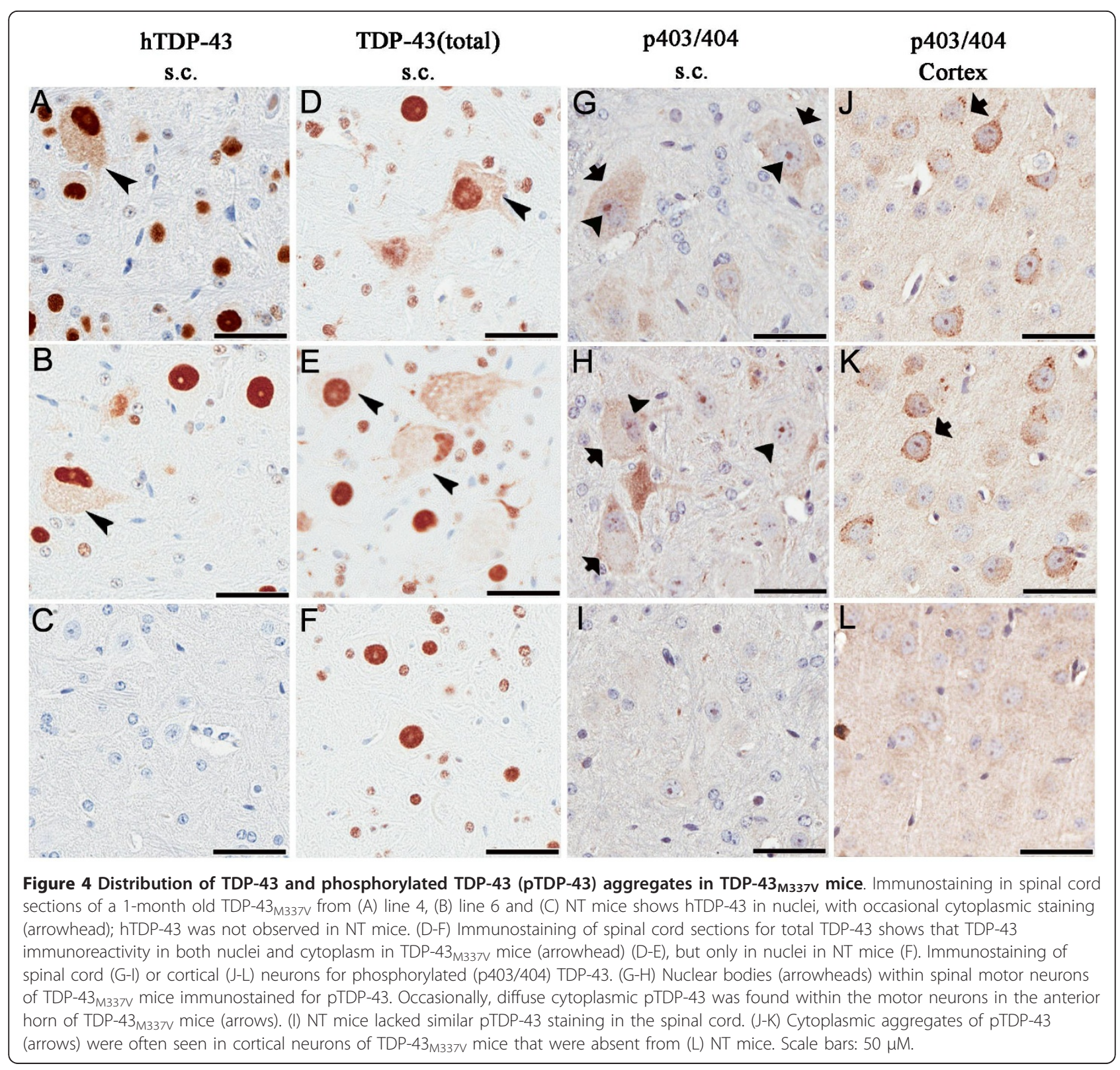

Table 1 Regional distribution of pathologies in TDP-43 ${ }_{\text {Mзз7v }}$ mice

\begin{tabular}{|c|c|c|c|c|c|c|c|}
\hline & $\begin{array}{c}\text { Cortex, layer } \\
\text { V }\end{array}$ & Hippocampus & Striatum & Brainstem & Cerebellum & $\begin{array}{l}\text { Anterior horn of spinal } \\
\text { cord }\end{array}$ & $\begin{array}{c}\text { Posterior horn of spinal } \\
\text { cord }\end{array}$ \\
\hline Cytoplasmic TDP-43 & + & - & - & + & - & ++ & + \\
\hline Nuclear pTDP-43 & - & - & - & $+/-$ & - & ++ & + \\
\hline Cytoplasmic pTDP-43 & ++ & - & - & + & - & ++ & + \\
\hline Ubiquitination & ++ & + & + & ++ & - & ++ & ++ \\
\hline $\begin{array}{l}\text { IBA-1-positive } \\
\text { microglia }\end{array}$ & + & - & - & ++ & - & ++ & + \\
\hline $\begin{array}{l}\text { GFAP-positive } \\
\text { astrocytes }\end{array}$ & + & - & - & ++ & - & ++ & + \\
\hline $\begin{array}{l}\text { Mitochondrial } \\
\text { aggregates }\end{array}$ & + & - & - & + & - & ++ & + \\
\hline p-tau & ++ & ++ & + & + & - & $+/-$ & $+/-$ \\
\hline
\end{tabular}



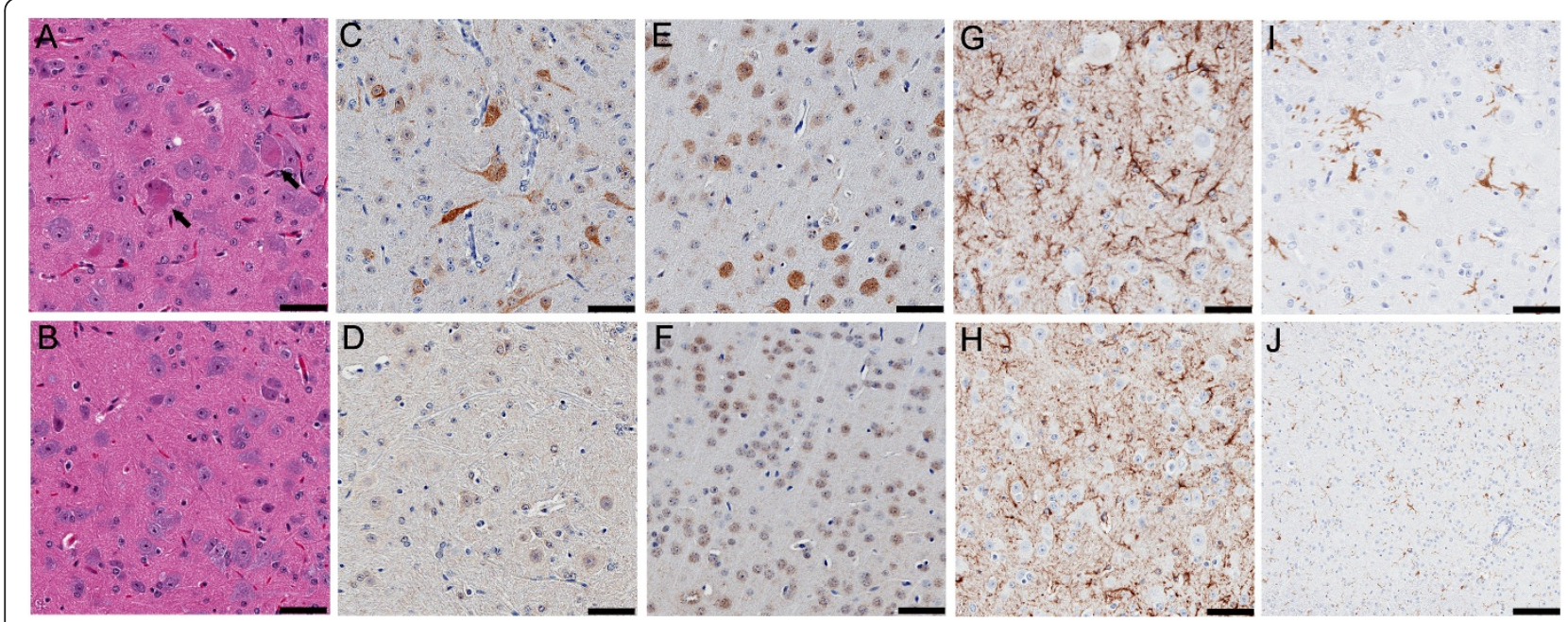

Figure 5 Neuropathology in TDP-43 ${ }_{\text {M3zт }}$ mice. Hematoxylin and eosin staining revealed (A, arrows) eosinophilic aggregates in spinal motor neurons from TDP-43 $3337 \mathrm{~V}$ mice that are not observed in (B) NT mice. Abnormal ubiquitin immunoreactivity was present in the cytoplasm and nucleus of neurons in the (C) spinal cord of TDP-43 $3_{\mathrm{M} 337 \mathrm{~V}}$ mice, but not in (D) NT mice. Similar ubiquitination was observed in the (E) cortex of TDP-43 $3337 \mathrm{~V}$ mice, but not in (F) NT mice. Enhanced (G-H) GFAP and (I-J) IBA-1 immunoreactivity indicative of reactive astrogliosis and activated microglia, respectively, were observed in TDP-43 ${ }_{M 337 v}$ mice $(G, I)$, but not NT mice $(H, J)$. Scale bars: $100 \mu M$.

and vacuolization (Figure 6E). The degenerating mitochondria in TDP-43 $3337 \mathrm{~V}$ mice (Figure 6E) were smaller than those in NT mice (Figure 6F). In NT mice, mitochondria were usually admixed with other cytoplasmic organelles such as endoplasmic reticulum and ribosome (Figure 6F); however, this intervening organelles were absent in the neuronal aggregates of TDP- $43_{\mathrm{M} 337 \mathrm{~V}}$ mice (Figure 6E). The mitochondrial aggregates in the TDP$43_{\mathrm{M} 337 \mathrm{~V}}$ mice were frequent in the spinal cord and brainstem, less frequent in the cortex, and rare in other brain regions (Table 1). Homozygous TDP $-43_{\mathrm{M} 337 \mathrm{~V}}$ mice from line 6 also developed juxtanuclear mitochondrial aggregates (not shown).

\section{M337V TDP-43 does not alter mitochondrial fusion and fission proteins}

We have previously demonstrated that mitochondrial clustering in neurons of TDP- $43_{\mathrm{WT}}$ mice is accompanied by changes in protein levels and/or phosphorylation of proteins that regulate mitochondrial fission and fusion [11]. Given the similarity between mitochondrial aggregates in TDP-43 $4337 \mathrm{~V}$ mice and our previously described TDP ${ }_{\mathrm{WT}}$ mice, we sought to determine if mitochondrial fission and fusion proteins were altered in the TDP $-43_{M 337 V}$ mice. Surprisingly, the alterations to pDLP1 (Ser616), Fis1, and MFN1 that were observed in the TDP $-43_{\mathrm{WT}}$ mice, regardless of line, were not present in the TDP- $43_{\mathrm{M} 337 \mathrm{~V}}$ mice, despite the comparable mitochondrial aggregation in each transgenic model (Additional file 2).

\section{Chromatolysis in TDP-43 ${ }_{\mathrm{M} 337 \mathrm{~V}}$ mice}

In the spinal motor neuron of TDP- $43_{\mathrm{M} 337 \mathrm{~V}}$ mice, Nissl bodies became dispersed (Figure 7A) compared to NT mice (Figure 7B). There was disintegration of chromophil substance primarily within the cell bodies of the spinal cords of TDP-43 $3337 \mathrm{~V}$ mice (Figure $7 \mathrm{C}$ ) that was not observed in NT mice (Figure 7D). Ultrastructural analysis showed reduced cytoplasmic density and less cytoplasmic organelles in TDP-43 $3337 \mathrm{~V}$ mice (Figure 7E) compared to NT mice (Figure 7F). These finding are indicative of chromatolysis and suggest that neurons in TDP- $43_{\mathrm{M} 337 \mathrm{~V}}$ mice are undergoing perikaryal response to axonal degeneration.

\section{Hyperphosphorylated tau accumulation in TDP-43 ${ }_{\mathrm{M} 337 \mathrm{~V}}$ and TDP-43 ${ }_{\text {WT }}$ mice}

Abnormal, phosphorylated tau was found in the brains of both TDP- $43_{\mathrm{WT}}$ and TDP- $43_{\mathrm{M} 337 \mathrm{~V}}$ mice. Immunohistochemical analyses of the cortices of TDP-43 $3_{\mathrm{M} 337 \mathrm{~V}}$ (Figure $8 \mathrm{~A}$ ) and TDP-43 $43_{\mathrm{WT}}$ mice (Figure $8 \mathrm{~B}$ ) showed significantly elevated phosphorylated tau (CP13) immunoreactivity throughout the neuropil of the brain compared with NT mice (Figure 8C). Additionally, cytoplasmic tau accumulations were found in the TDP$43_{\mathrm{WT}}$ mice and much less frequently in the TDP$43_{\mathrm{M} 337 \mathrm{~V}}$ mice (Figure $8 \mathrm{~A}, \mathrm{~B}$ ). Western blots of brain lysates showed that the levels of phosphorylated tau (CP13) were significantly increased in both the TDP$43_{\mathrm{WT}}$ and TDP $-43_{\mathrm{M} 337 \mathrm{~V}}$ mice (Figure $8 \mathrm{D}$ ), while the level of dephosphorylated tau (Tau-1) was dramatically decreased. There was no significant change in the level 


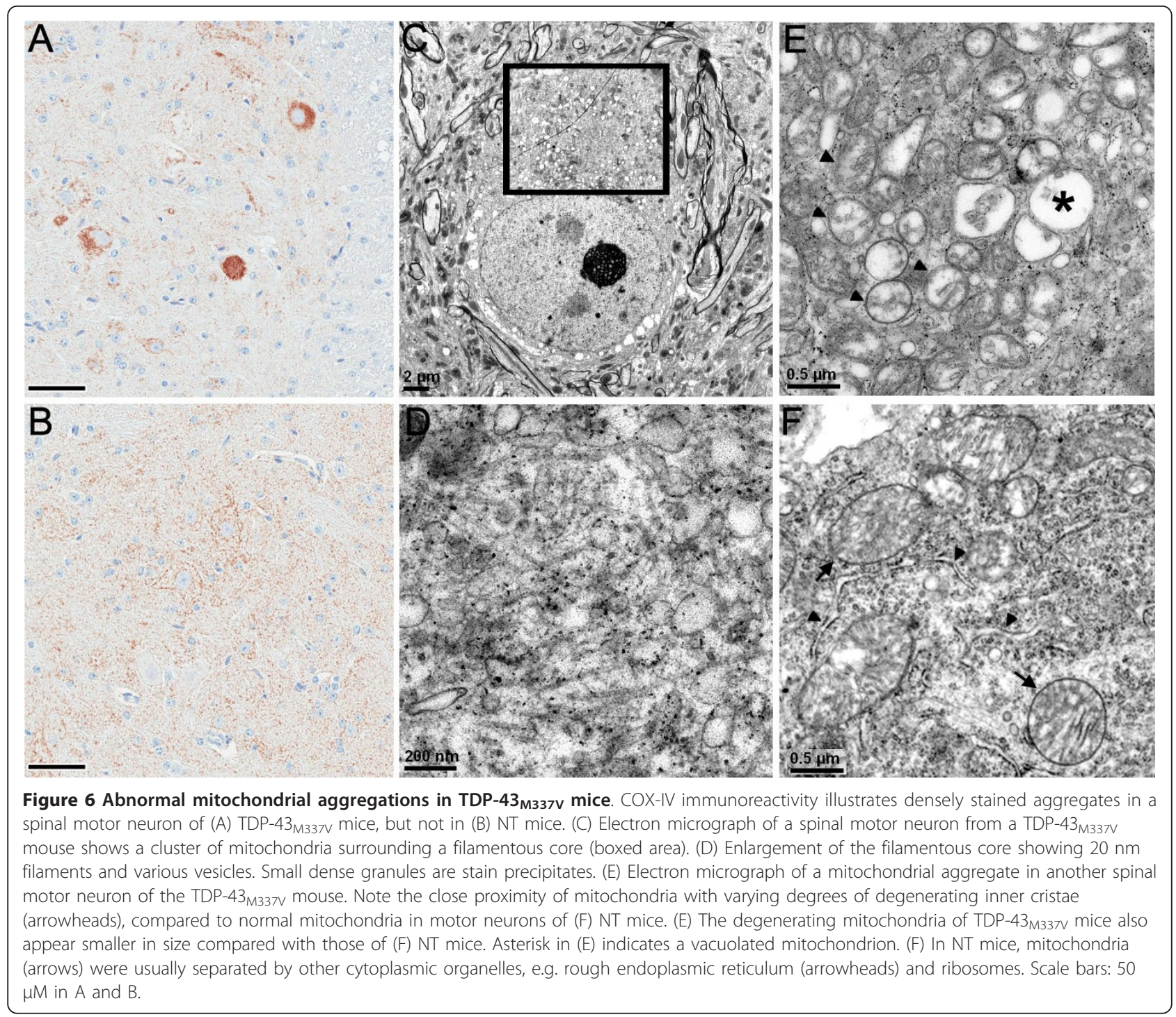

of total tau (Tau-5) (Figure 8D). To explore the mechanism for tau phosphorylation, we examined protein kinases and phosphatases and found significant increases in phospho-(Ser) PKC substrate in both TDP$43_{\mathrm{WT}}$ and TDP-43 $3_{\mathrm{M} 337 \mathrm{~V}}$ mice, indicating PKC activation may be responsible for such abnormal tau phosphorylation (Figure 8D). The levels of other tau kinases, such as GSK-3 $\beta$ and CDK5, and the tau phosphatase PP2A were not significantly changed in the TDP- $43_{\mathrm{M} 337 \mathrm{~V}}$ and TDP$43_{\text {WT }}$ mice (data not shown). Abnormally phosphorylated tau was rarely found in the spinal cord (data not shown). The regional distribution of hyperphosphorylated tau is summarized in Table 1.

\section{Discussion}

In the current study, we generated and characterized a novel transgenic mouse model that overexpresses
hTDP-43 carrying the M337V mutation under the mouse prion promoter. Homozygous TDP-43 M337V mice (referred to as TDP- $43_{\mathrm{M} 337 \mathrm{~V}}$ mice) develop phenotypic and pathologic features including gait disturbances, gliosis, increased ubiquitination, TDP-43 truncation, phosphorylation, and both nuclear and cytoplasmic phosphorylated inclusions.

Importantly, the novel findings described in the current manuscript and the counterpart TDP $-43_{\mathrm{WT}}$ mice manuscript [11], demonstrate expression of human TDP-43 at similar levels results in remarkably similar phenotypes and pathologies, suggesting that the phenotypes of both models are due to TDP-43 overexpression, and not specifically due to this mutation. Previously published findings regarding TDP-43 overexpression in mouse models strongly suggested that overexpression of TDP-43 itself is toxic; however, none of these studies 


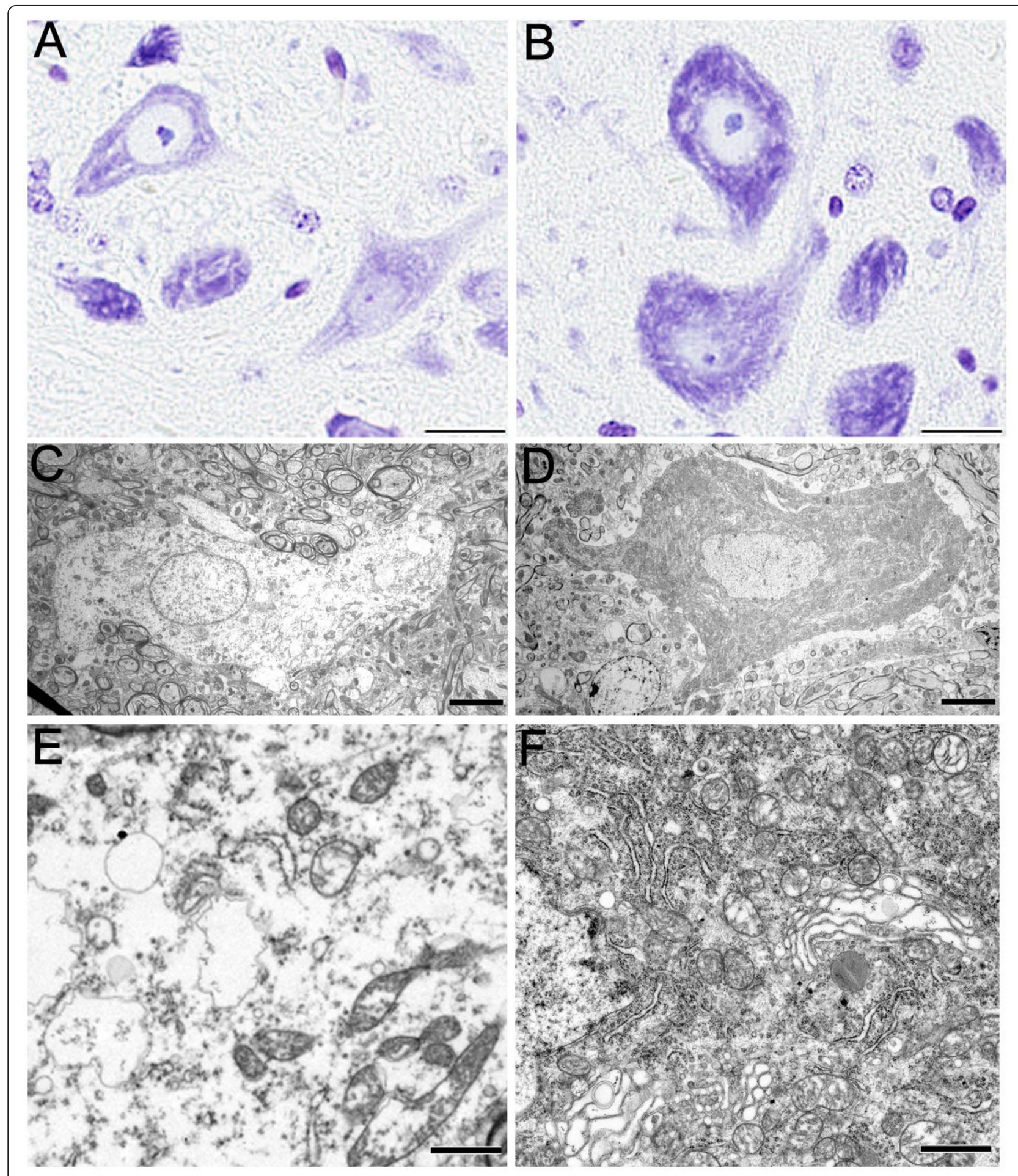

Figure 7 Chromatolysis in TDP-43 $\mathbf{M}_{\mathbf{M} 37 \mathrm{~V}}$ mice. Nissl staining of motor neurons of (A) TDP-43 ${ }_{\mathrm{M} 337 \mathrm{~V}}$ mice is much weaker than that in (B) NT mice. (C) Electron micrograph of a chromatolytic neuron of TDP-43 rarefaction of cytoplasmic organelles (E), compared with the normal cytoplasmic density (D) and packed organelles (F) of NT mice. Scale bars: 20 $\mu \mathrm{M}$ in $\mathrm{A}$ and $\mathrm{B} ; 5 \mu \mathrm{M}$ in $\mathrm{C}$ and $\mathrm{D}$; and $1 \mu \mathrm{M}$ in $\mathrm{E}$ and $\mathrm{F}$. 


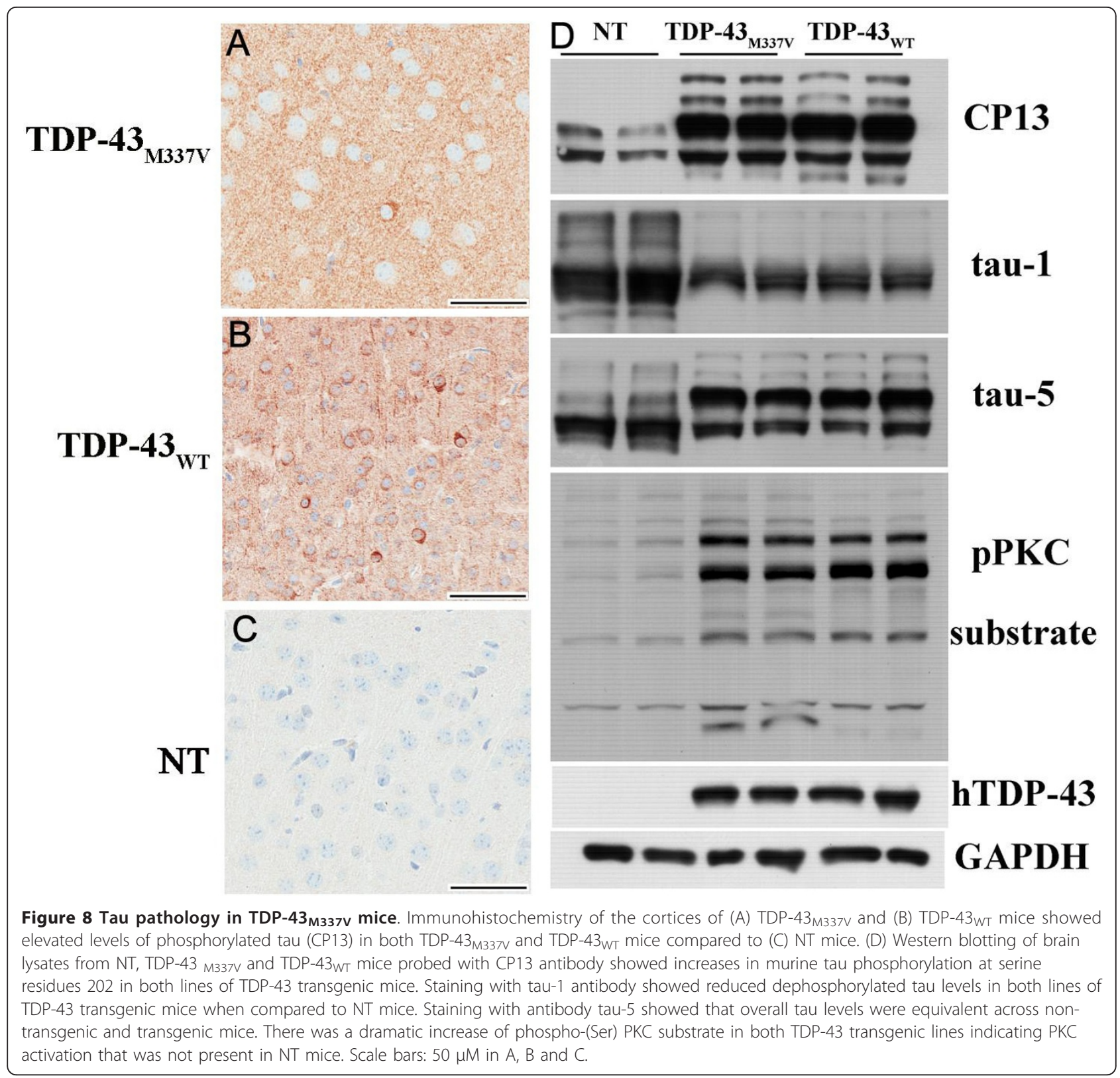

have included mutant TDP-43 lines that were comparable in expression level and pattern, promoter system, and strain to WT TDP-43 counterparts [10-16]. In constitutive transgenic rat studies, Zhou and colleagues reported that mutant M337V TDP-43 appeared to be more toxic than wild-type TDP-43 [18] even though the animals expressed the hTDP-43 protein at similar levels. It is unclear why there is a discrepancy between our mutant and wild-type TDP-43 transgenic models and those in the rat. One possibility could be the difference of promoters utilized in the studies. Additionally, Zhou and colleagues did not look at endogenous rat TDP-43 levels in response to the hTDP-43 overexpression [18]; therefore, it is possible that differences in endogenous TDP-43 played a role in the rat phenotype. Moreover, in contrast to our hTDP-43 cDNA construct, the constitutive hTDP-43 construct utilized by Zhou and colleagues is a hTDP-43 minigene [18], which appears to contain 3'UTR and binding regions that have been shown recently to be required for autoregulation of TDP-43 $[19,20]$. Given this, it is possible that the hTDP43 in the constitutive rat model is also autoregulated and that the presence of the mutation in the hTDP-43 minigene prevents autoregulation of the mutant, but not the wild-type, hTDP-43. Finally, in the TDP-43 rat models, there appears to be extensive hTDP-43 
immunoreactivity in both the nucleus and the cytoplasm, regardless of mutation; whereas, TDP-43 mainly localized in the nuclei in both of our TDP-43 $3_{\mathrm{M} 337 \mathrm{~V}}$ and TDP-43 3 W mice. The toxicity that we observe in our TDP-43 transgenic mice is therefore likely to be due, at least in part, to the impact of high TDP-43 levels on nuclear functions. Overexpression of TDP-43 in the nuclei of TDP-43 mice may interfere with interaction with its DNA and RNA targets, disrupt normal substrate metabolism and lead to neuronal dysfunction. Recent efforts to identify neuronal RNA targets of TDP-43 implicated in neurodegeneration led to the identification of FUS/TLS, progranulin, tau and ataxin 1 and -2 and TDP-43 itself [20-22]. Additional studies are needed to explore the precise roles of TDP-43 DNA/RNA targets at work in these mouse models. Both TDP-43 LMW species and cytoplasmic TDP-43 are present in our TDP-43 mice, and they may also contribute to the pathologies and abnormal behavior.

Our results showed that overexpression of hTDP$43_{\mathrm{M} 337 \mathrm{~V}}$ can down regulate endogenous mouse TDP-43 levels, which is consistent with the property of TDP-43 autoregulation. TDP-43 can autoregulate its mRNA level, in part by directly binding to the 3'UTR of its own transcript, thereby triggering exosome-mediated degradation or nonsense-mediated RNA degradation $[19,20]$. The C-terminal region (a.a 321-366) of TDP-43 is required for autoregulation [19]. Recent reports allow for the possibility that mutation of TDP-43 within the C-terminus may affect the efficiency of autoregulation; however, the presence of the M337V mutant within hTDP-43 did not impair its ability to regulate endogenous mTDP-43. The loss of nuclear mTDP-43 in response to hTDP- $43_{\mathrm{M} 337 \mathrm{~V}}$ overexpression has been proposed to play a role in the pathogenesis observed in another TDP-43 transgenic mouse model [14]. Considering the substantial homology between the hTDP$43_{\mathrm{M} 337 \mathrm{~V}}$ and mTDP-43 proteins, it would seem likely that hTDP- $43_{\mathrm{M} 337 \mathrm{~V}}$ might functionally compensate for the loss of mTDP-43, but we cannot exclude the possibility that loss of nuclear mTDP-43 may contribute to the phenotype of hTDP- $43_{\mathrm{M} 337 \mathrm{~V}}$ transgenic mice.

Abnormal mitochondrial accumulation has now been observed in both our TDP- $43_{\mathrm{M} 337 \mathrm{~V}}$ and TDP- $43_{\mathrm{WT}}$ mice [11] and in another wild-type TDP-43 overexpressing mouse model driven by Thy1.2 promoter [13], suggesting that TDP-43 can regulate mitochondrial dynamics. In addition to clustering of mitochondria, the size and the ultrastructural integrity of neuronal mitochondria was reduced in our TDP-43 mice compared with mitochondria of NT mice. In the TDP- $43_{\mathrm{WT}}$ mice, we had previously identified changes in levels and the phosphorylation state for proteins that critically regulate mitochondrial fission and fusion and suggested that these changes may contribute to the abnormal aggregation and morphology of mitochondria. Surprisingly, we did not find similar changes in mitochondrial fission and fusion proteins in the TDP-43 $3_{\mathrm{M} 337 \mathrm{~V}}$ mice, suggesting that mitochondrial aggregation observed in both TDP43 models may result from another pathogenic processes, such as axonal degeneration.

On occasion, mitochondrial clusters within the neurons of the TDP- $43_{\mathrm{M} 337 \mathrm{~V}}$ mice were associated with microtubules. TDP-43 may alter the microtubule-based mitochondrial transportation system and lead to both microtubule and mitochondrial aggregation and dysfunction. While there are a number of ways through which this could occur, it was interesting to find that the microtubule associated protein tau was abnormally hyperphosphorylated in the brain of both our TDP- $43_{\mathrm{WT}}$ and TDP- $43_{\mathrm{M} 337 \mathrm{~V}}$ mice. Tau functions to stabilize microtubules and to facilitate axonal transport. Abnormal phosphorylation of tau can reduce its ability to bind microtubules [23]. A number of kinases can phosphorylate tau, and one of these kinases, PKC, was activated in both TDP-43 $3_{\mathrm{M} 337 \mathrm{~V}}$ and TDP-43 $3_{\mathrm{WT}}$ mice. Tau hyperphosphorylation might be partially due to PKC activation in the mice; however, the paradigm through which TDP-43 overexpression resulted in tau hyperphosphorylation and/or PKC activation is still unclear. One possibility is that exacerbated TDP-43 autoregulation disrupts the homeostasis of other key proteins and eventually leads to dysfunction. Alternatively, PKC activation and tau hyperphosphorylation could be secondary or unrelated to mitochondrial clustering. There is a large body of evidence suggesting that axonal transport is disrupted in ALS $[24,25]$, which includes evidence that SOD1 mutations impair axonal transport [26,27]. Interestingly, depletion of kinesin heavy chain (kif5B) results in mitochondrial perinuclear clusters similar to those described in our TDP-43 models [28].

One limitation of our model is that although many of the features are consistent with those observed in ALS, there are several features of this model that are incongruous with the human disease. Phenotypically, our mice show retarded growth from early life; whereas, humans with ALS typically show progressive disease after initially normal development into adulthood. While our TDP $-43_{\mathrm{M} 337 \mathrm{~V}}$ mice show early lethality, the age at death for the mice is significantly younger in comparison to the lifespan of humans with ALS due to mutations in TDP-43. We did not see loss of nuclear TDP-43 immunoreactivity similar to that observed in affected neurons in ALS, even in cells with cytoplasmic TDP-43 inclusions. It is possible that mTDP-43 underwent redistribution as recently reported in another TDP-43 mouse model [14]; however, we are unable to confirm this due to unavailability of mTDP-43-specific antibody. We also observed considerable chromatolysis in the TDP- 
$43_{\mathrm{M} 337 \mathrm{~V}}$ mice; however, chromatolysis is infrequent in end stage human ALS, and often only detected in cases with rapid disease progression [29]. TDP-43 $3337 \mathrm{~V}$ mice also exhibit other pathologies not frequently seen in humans, such as abnormal mitochondrial aggregation. Interestingly, increased phospho-tau has been reported in ALS patients, especially those with cognitive impairment [30,31], which suggests that further analysis of a potential relationship between TDP-43 and tau in mouse models and in human cases might be warranted. The motor, biochemical, and pathological features observed in TDP- $43_{\mathrm{M} 337 \mathrm{~V}}$ mice (line 4) were also noted in a second independent line of TDP- $43_{\mathrm{M} 337 \mathrm{~V}}$ mice (line 6), suggesting that these features were not simply due to transgene insertional effects.

We observed some regional differences in our TDP-43 transgenic models, despite the relatively uniform expression of the TDP-43 proteins throughout the gray matter of the brain and spinal cord. For example, nuclear pTDP43 inclusions, abnormal mitochondrial aggregation and chromatolysis were mainly observed in spinal cord, while cytoplasm pTDP-43 inclusions and tau phosphorylation were primarily seen in the brain. This indicates that the mechanisms regulating TDP-43 and being regulated by TDP-43 are likely to be different in the brain and spinal cord and warrant further investigation.

\section{Conclusion}

In summary, this novel TDP- $43_{\mathrm{M} 337 \mathrm{~V}}$ mouse model indicates that overexpression of hTDP- $43_{\mathrm{M} 337 \mathrm{~V}}$ alone is toxic in vivo. TDP- $43_{\mathrm{M} 337 \mathrm{~V}}$ mice recapitulate certain pathologic features seen in neurodegenerative diseases, including TDP-43 fragmentation, phosphorylation, aggregation, increased ubiquitination and gliosis. While these features could also indicate general neuronal dysfunction, the mice also exhibit down regulation of mouse TDP-43, abnormal mitochondria aggregation and abnormal tau phosphorylation. Because overexpression of mutant hTDP-43 produces phenotypes similar to the wild-type TDP-43 model, the mechanisms causing pathogenesis in the mutant model remain unknown. However, these results should not be surprising, given the mutant TDP43 and wild-type TDP- 43 biochemically are similar in human disease. As such, the TDP- $43_{\mathrm{M} 337 \mathrm{~V}}$ mice may serve as a valuable tool for future studies of yet-to-beexamined disease pathways and the precise roles TDP-43 RNA targets play in neurodegeneration.

\section{Methods}

\section{Generation of TDP-43 $3_{\text {M337v }}$ Transgenic Mice}

The human wild-type TDP-43 cDNA was generated as previously described [11] and was inserted into the XhoI site of the pcDNA 3.1. To generate the M337V mutation, site directed mutagenesis was performed using
Quikchange kit (Strategene). The primers used for the mutation were: 5'-CAGTTGGGGTATGGTGGGCATGTTAGC-3' and 5'-GCTAACATGCCCACCATACCCCAACTG-3'. After confirming the mutation by sequencing, the M337V TDP-43 cDNA was inserted into the XhoI site of MoPrP vector [17]. Following sequencing, the construct was linearized with NotI, gel purified and digested with $\beta$-agarose. DNA was filtered, concentrated and diluted to $3 \mathrm{ng} / \mu \mathrm{l}$ in microinjection buffer. The transgene was microinjected into fertilized C57BL/6 (B6) mouse eggs and re-implanted into pseudopregnant females. Eight founders were mated with B6 mice to determine germline transmission and establish expression levels. TDP-43 founder lines (line 4 and 6) that have similar transgene levels to the TDP- $43_{\mathrm{WT}}$ mice we previously described [11], were used for all subsequent experiments. Homozygous mice were produced through a crossbreeding of transgenic mice from the same line. At no time were lines 4 and 6 intercrossed. Procedures were performed in accordance with the Mayo Institutional Animal Care and Use Committee.

\section{Genotyping}

Transgenic mice were identified by PCR using hTDP43-specific primers: 5' - TGGAGAAGTTCTTATGGTGCAGGTC-3' and 5'-GGTATTAGCCTATGGGGGACAC-3' against control actin-specific primers (5'CGGAACCGCTCATTGCC-3' and 5'-ACCCACACTGTGCCCATCTA-3'). Homozygous mice were identified by Quantitative real-time PCR (see Quantitative real-time PCR section).

\section{Quantitative real-time PCR}

Levels of human and mouse TDP-43 transcripts were determined via TaqMan $^{\circledR}$ Gene Expression Assays (Applied Biosystems, Carlsbad, CA). Total RNA was isolated either from tail samples for identification of homozygous mice or from brain or spinal cord tissue to determine the levels of human and mouse TDP-43 transcripts. TRIzol (Invitrogen, Carlsbad, CA) and Pure Link $^{\text {TM }}$ RNA Mini Kit (Invitrogen, Carlsbad, CA) were used for RNA extraction. $3 \mu \mathrm{g}$ RNA were used to synthesize cDNA using the High Capacity cDNA Reverse Transcription Kit (Applied Biosystems, Carlsbad, CA). The qPCR assay used the following: hTDP-43 Hs00606522_m1, mTDP-43 Mm00523866_m and 18S rRNA Hs99999901_s1. The PCR was run on the ABI 7900 and data analyzed using Software RQ Manager 1.2 (Applied Biosystems, Carlsbad, CA).

\section{Tissue preparation}

Sagittal half brain and spinal column were immersion fixed in $10 \%$ formalin for immunohistochemistry, and the other half brain was frozen on dry ice for 
biochemistry. After 24 hours, the spinal cord was removed from the vertebral column and fixed overnight.

\section{Western Blotting}

Tissues were homogenized at $10 \mathrm{ml} / \mathrm{g}$ (volume/weight) in lysis buffer (50 mM Tris- $\mathrm{HCl}, \mathrm{pH}$ 7.4, $300 \mathrm{mM} \mathrm{NaCl}, 1 \%$ Triton X-100, 5 mM EDTA, 2\% SDS, PMSF, and protease and phosphatase inhibitor). Following centrifugation, supernatant was assessed by BCA assay (Pierce, Rockford, IL). Following western blotting, membranes were incubated with mouse monoclonal TDP-43 antibody, which was generated using amino acids 1 to 261 of hTDP-43 as the immunogen and was found to recognize amino acids 205-222 of hTDP-43 by epitope mapping [32]; rabbit polyclonal TDP-43 antibody against amino acids 288-441; mouse CP13; mouse Tau 5; mouse tau-1; mouse monoclonal glyceraldehyde-3-phosphate dehydrogenase (GAPDH) antibody; Phospho-(Ser) PKC Substrate Antibody; mouseDLP1 antibody; rabbit phospho-DLP1 (Ser616) antibody; rabbit Fis1 antibody; or mouse mitofu$\sin 1$ antibody. See Additional file 3 for a complete list of primary antibodies used. Following incubation with an appropriate secondary antibody, immunoreactivity was visualized by ECL and exposure to film.

\section{Immunohistochemistry (IHC) and histochemistry}

Tissues were embedded in paraffin, sectioned ( $5 \mu \mathrm{m}$ thick) and mounted on glass slides. Sections were deparaffinized in xylene and rehydrated in a graded series of alcohol, followed by $\mathrm{dH}_{2} \mathrm{O}$. Antigen retrieval was performed in a $\mathrm{dH}_{2} \mathrm{O}$ steam bath for $30 \mathrm{~min}$. Tissues were immunostained with monoclonal TDP-43 antibody or antibodies toward pS403/S404-phosphorylated TDP-43, ubiquitin, glial fibrillary acidic protein (GFAP), ionized calcium-binding adaptor molecule 1 (IBA-1), cytochrome oxidase subunit IV (COX-IV), or phospho-tau (CP13; pS202 tau) using the DAKO Autostainer (Dako Auto Machine Corporation) and the DAKO EnVision+ HRP system. DAKO Liquid DAB Substrate-Chromogen system was the chromogen. See Additional file 3 for a complete list of primary antibodies used. After immunostaining, sections were briefly counterstained with hematoxylin to stain cell nuclei and coverslipped. Paraffin-embedded sections were also stained with hematoxylin and eosin.

\section{Electron Microscopy}

Spinal cords from 4\%-paraformaldehyde-perfused mice were immersed in $2.5 \%$ glutaraldehyde- $0.1 \mathrm{M}$ cacodylate buffer, post-fixed in $1 \% \mathrm{OsO}_{4}$, dehydrated in alcohol and propylene oxide, and finally infiltrated and embedded in Epon 812. Ultrathin sections mounted on copper grids were stained with uranyl acetate and lead citrate. Images were obtained with a Gatan CCD camera using a Philips $208 \mathrm{~S}$ electron microscope.

\section{Gait Analysis Methods}

Front paws were painted red, and hind feet were painted blue with nontoxic paint. The mice were placed in a plastic tunnel with a strip of white paper covering the floor. At the end of the tunnel was an enclosed black box to encourage mice to cross the paper and into the box. The test was repeated until mice left at least five pairs of adjacent footprints.

\section{Statistics}

One-way ANOVA with Tukey's posthoc analysis were used to compare measures among 3 groups. Student's t-test analysis was used to compare measures between 2 groups. Kaplan-Meier methods were used for survival analysis. For data presentation, normalized values were averaged and presented as mean \pm standard error of means (SEM). Values of $p<0.05$ were considered statistically significant.

\section{Additional material}

\begin{abstract}
Additional file 1: Figure A1: Increased ubiquitin levels in TDP$43_{\text {Mз37V }}$ mice but hTDP-43 itself is not ubiquitinated. Human TDP-43 was immunoprecipitated from brain homogenates derived from nontransgenic and homozygous TDP- $43_{\text {m337v }}$ mice. Briefly, brain homogenates containing $500 \mu \mathrm{g}$ protein were incubated with $1.5 \mathrm{\mu g}$ mouse monoclonal TDP-43 antibody overnight at $4^{\circ} \mathrm{C}$ with gentle shaking. Protein $\mathrm{G}$ agarose was added for $4 \mathrm{~h}$ at $4^{\circ} \mathrm{C}$ then pelleted by centrifugation. Protein thus captured was eluted using sample loading buffer and resolved by SDS/PAGE for Western blot analysis. Shown are immunoblots of the inputs and the immunoprecipitated proteins, probed using an antibody to ubiquitin or to total TDP-43. Note that a marked increase in ubiquitin levels is observed in the homogenates derived from homozygous mice prior to immunoprecipitation. Nonetheless, the immunoprecipitated human TDP-43 is not immunopositive for ubiquitin. Arrow $=\lg G$ Heavy Chain.

Additional file 2: Figure A2: No mitochondrial fission and fusion protein changes in TDP-43 ${ }_{\text {M337V }}$ mice. Immunoblot analysis of Ser616phosphorylated DLP1, DLP1, Fis1, and mitofusin 1 (MFN1) expression level in brain lysates of nontransgenic(NT), hemizygous(Hemi), and homozygous(Homo) TDP-43 $3_{\text {M337V }}$ mice of both line 4 and line 6. There are no significant protein changes among different mice groups.

Additional file 3: Additional Table: Primary Antibody List. Full list of the primary antibodies used in this study.
\end{abstract}

\section{List of abbreviations}

ALS: amyotrophic lateral sclerosis; FTLD-U: frontotemporal lobar degeneration with ubiquitin-positive inclusions; TDP-43: TAR DNA binding protein-43; hTDP-43: human TDP-43; mTDP-43: mouse TDP-43. pTDP-43: phospho-TDP-43.

\section{Acknowledgements}

This work was supported by the AFAR Affiliate Research Grant Program (YZ), Mayo Clinic Foundation (DWD, JL, LP), National Institutes of Health/National Institute on Aging [5R01AG026251-04 and P01-AG17216-08 (LP)], National Institutes of Health/National Institute of Neurological Disorders and Stroke [R01 NS 063964-01 (LP) and 1R21NS071097-01 (JL)], Amyotrophic Lateral Sclerosis Association (LP, JL) and Department of Defense [USAMRMC PR080354 (LP, JL) and AL093108 (LP)]. We would like to thank Jimei Tong, Cindy Yu, Monica Castanedes-Casey, Linda Rousseau and Virginia Phillips for technical support. 


\section{Author details}

'Department of Neuroscience, Mayo Clinic, (4500 San Pablo Road), Jacksonville, (32224), USA. ${ }^{2}$ Center for Translational Research in Neurodegenerative Disease (CTRND), College of Medicine, University of Florida, (1275 Center Drive), Gainesville, (32610), USA. ${ }^{3}$ Department of Neuroscience, College of Medicine, University of Florida, (1275 Center Drive), Gainesville, (32610), USA

\section{Authors' contributions}

$Y X$ and $Y Z$ performed experiments, data analysis and co-wrote the manuscript. XC performed experiments, WL performed Electron Microscopy study. CS edited the manuscript. JL, DWD and LP conceived of the study, participated in its design and coordination and edited the manuscript. All authors read and approved the final manuscript.

\section{Competing interests}

$Y X, Y Z$, JL, and LP are inventors of this and related mouse models; however, no royalties have been generated from this invention.

Received: 29 April 2011 Accepted: 26 October 2011

Published: 26 October 2011

\section{References}

1. Arai T, Hasegawa M, Akiyama H, Ikeda K, Nonaka T, Mori H, Mann D, Tsuchiya K, Yoshida M, Hashizume Y, Oda T: TDP-43 is a component of ubiquitin-positive tau-negative inclusions in frontotemporal lobar degeneration and amyotrophic lateral sclerosis. Biochem Biophys Res Commun 2006, 351:602-611.

2. Neumann M, Sampathu DM, Kwong LK, Truax AC, Micsenyi MC, Chou TT, Bruce J, Schuck T, Grossman M, Clark CM, et al: Ubiquitinated TDP-43 in frontotemporal lobar degeneration and amyotrophic lateral sclerosis. Science 2006, 314:130-133.

3. Sreedharan J, Blair IP, Tripathi VB, Hu X, Vance C, Rogelj B, Ackerley S, Durnall JC, Williams KL, Buratti E, et al: TDP-43 mutations in familial and sporadic amyotrophic lateral sclerosis. Science 2008, 319:1668-1672.

4. Kabashi E, Valdmanis PN, Dion P, Spiegelman D, McConkey BJ, Vande Velde C, Bouchard JP, Lacomblez L, Pochigaeva K, Salachas F, et al: TARDBP mutations in individuals with sporadic and familial amyotrophic lateral sclerosis. Nat Genet 2008, 40:572-574.

5. Gitcho MA, Baloh RH, Chakraverty S, Mayo K, Norton JB, Levitch D, Hatanpaa KJ, White CL, Bigio EH, Caselli R, et al: TDP-43 A315T mutation in familial motor neuron disease. Ann Neurol 2008, 63:535-538.

6. Rutherford NJ, Zhang YJ, Baker M, Gass JM, Finch NA, Xu YF, Stewart H, Kelley BJ, Kuntz K, Crook R, et al: Novel mutations in TARDBP (TDP-43) in patients with familial amyotrophic lateral sclerosis. PLoS Genet 2008, 4:e1000193.

7. Yokoseki A, Shiga A, Tan CF, Tagawa A, Kaneko H, Koyama A, Eguchi H, Tsujino A, Ikeuchi T, Kakita A, et al: TDP-43 mutation in familial amyotrophic lateral sclerosis. Ann Neurol 2008, 63:538-542.

8. Buratti E, Dork T, Zuccato E, Pagani F, Romano M, Baralle FE: Nuclear factor TDP-43 and SR proteins promote in vitro and in vivo CFTR exon 9 skipping. EMBO J 2001, 20:1774-1784.

9. Buratti E, Baralle FE: Multiple roles of TDP-43 in gene expression, splicing regulation, and human disease. Front Biosci 2008, 13:867-878.

10. Wils $H$, Kleinberger $G$, Janssens J, Pereson $S$, Joris G, Cuijt I, Smits V, Ceuterick-de Groote C, Van Broeckhoven C, Kumar-Singh S: TDP-43 transgenic mice develop spastic paralysis and neuronal inclusions characteristic of ALS and frontotemporal lobar degeneration. Proc Natl Acad Sci USA 2010, 107:3858-3863.

11. Xu YF, Gendron TF, Zhang YJ, Lin WL, D'Alton S, Sheng H, Casey MC, Tong J, Knight J, Yu X, et al: Wild-type human TDP-43 expression causes TDP-43 phosphorylation, mitochondrial aggregation, motor deficits, and early mortality in transgenic mice. J Neurosci 2010, 30:10851-10859.

12. Wegorzewska I, Bell S, Cairns NJ, Miller TM, Baloh RH: TDP-43 mutant transgenic mice develop features of ALS and frontotemporal lobar degeneration. Proc Natl Acad Sci USA 2009, 106:18809-18814.

13. Shan X, Chiang PM, Price DL, Wong PC: Altered distributions of Gemini of coiled bodies and mitochondria in motor neurons of TDP-43 transgenic mice. Proc Natl Acad Sci USA 2010, 107:16325-16330.

14. Igaz LM, Kwong LK, Lee EB, Chen-Plotkin A, Swanson E, Unger T, Malunda J, Xu Y, Winton MJ, Trojanowski JQ, Lee VM: Dysregulation of the ALS- associated gene TDP-43 leads to neuronal death and degeneration in mice. J Clin Invest 2011, 121:726-738.

15. Tsai KJ, Yang CH, Fang YH, Cho KH, Chien WL, Wang WT, Wu TW, Lin CP, Fu WM, Shen CK: Elevated expression of TDP-43 in the forebrain of mice is sufficient to cause neurological and pathological phenotypes mimicking FTLD-U. J Exp Med 2010, 207:1661-1673.

16. Swarup V, Phaneuf D, Bareil C, Robertson J, Rouleau GA, Kriz J, Julien JP: Pathological hallmarks of amyotrophic lateral sclerosis/frontotemporal lobar degeneration in transgenic mice produced with TDP-43 genomic fragments. Brain 2011, 134:2610-2626.

17. Borchelt DR, Davis J, Fischer M, Lee MK, Slunt HH, Ratovitsky T, Regard J, Copeland NG, Jenkins NA, Sisodia SS, Price DL: A vector for expressing foreign genes in the brains and hearts of transgenic mice. Genet Anal 1996, 13:159-163.

18. Zhou H, Huang C, Chen H, Wang D, Landel CP, Xia PY, Bowser R, Liu YJ, Xia XG: Transgenic rat model of neurodegeneration caused by mutation in the TDP gene. PLoS Genet 2010, 6:e1000887.

19. Ayala YM, De Conti L, Avendano-Vazquez SE, Dhir A, Romano M, D'Ambrogio A, Tollervey J, Ule J, Baralle M, Buratti E, Baralle FE: TDP-43 regulates its mRNA levels through a negative feedback loop. EMBO J 2011, 30:277-288.

20. Polymenidou M, Lagier-Tourenne C, Hutt KR, Huelga SC, Moran J, Liang TY, Ling SC, Sun E, Wancewicz E, Mazur C, et al: Long pre-mRNA depletion and RNA missplicing contribute to neuronal vulnerability from loss of TDP-43. Nat Neurosci 2011

21. Sephton CF, Cenik C, Kucukural A, Dammer EB, Cenik B, Han Y, Dewey CM Roth FP, Herz J, Peng J, et al: Identification of neuronal RNA targets of TDP-43-containing ribonucleoprotein complexes. J Biol Chem 2011, 286:1204-1215

22. Tollervey JR, Curk T, Rogelj B, Briese M, Cereda M, Kayikci M, Konig J, Hortobagyi T, Nishimura AL, Zupunski V et al: Characterizing the RNA targets and position-dependent splicing regulation by TDP-43. Nat Neurosci 2011

23. Gendron TF, Petrucelli L: The role of tau in neurodegeneration. $\mathrm{Mol}$ Neurodegener 2009, 4:13.

24. Rothstein JD: Current hypotheses for the underlying biology of amyotrophic lateral sclerosis. Ann Neurol 2009, 65(Suppl 1):S3-9.

25. De Vos KJ, Grierson AJ, Ackerley S, Miller CC: Role of axonal transport in neurodegenerative diseases. Annu Rev Neurosci 2008, 31:151-173.

26. De Vos KJ, Chapman AL, Tennant ME, Manser C, Tudor EL, Lau KF, Brownlees J, Ackerley S, Shaw PJ, McLoughlin DM, et al: Familial amyotrophic lateral sclerosis-linked SOD1 mutants perturb fast axonal transport to reduce axonal mitochondria content. Hum Mol Genet 2007, 16:2720-2728.

27. Tateno M, Kato S, Sakurai T, Nukina N, Takahashi R, Araki T: Mutant SOD1 impairs axonal transport of choline acetyltransferase and acetylcholine release by sequestering KAP3. Hum Mol Genet 2009, 18:942-955.

28. Tanaka Y, Kanai Y, Okada Y, Nonaka S, Takeda S, Harada A, Hirokawa N: Targeted disruption of mouse conventional kinesin heavy chain, kif5B, results in abnormal perinuclear clustering of mitochondria. Cell 1998, 93:1147-1158.

29. Wakayama I: Morphometry of spinal motor neurons in amyotrophic lateral sclerosis with special reference to chromatolysis and intracytoplasmic inclusion bodies. Brain Res 1992, 586:12-18.

30. Strong MJ, Yang W, Strong WL, Leystra-Lantz C, Jaffe H, Pant HC: Tau protein hyperphosphorylation in sporadic ALS with cognitive impairment. Neurology 2006, 66:1770-1771.

31. Yang W, Sopper MM, Leystra-Lantz C, Strong MJ: Microtubule-associated tau protein positive neuronal and glial inclusions in ALS. Neurology 2003, 61:1766-1773.

32. Zhang HX, Tanji K, Mori F, Wakabayashi K: Epitope mapping of 2E2-D3, a monoclonal antibody directed against human TDP-43. Neurosci Lett 2008, 434:170-174.

doi:10.1186/1750-1326-6-73

Cite this article as: Xu et al: Expression of mutant TDP-43 induces neuronal dysfunction in transgenic mice. Molecular Neurodegeneration 2011 6:73. 